\title{
APPLICATION OF LOGISTICS PRINCIPLES FOR THE PURPOSES OF INTEREST INCREASE IN THE SPIŠ REGION
}

\author{
Dominika Szabóová \\ TU of Košice, Faculty BERG, Logistics Institute of Industry and Transport, Park Komenského 14, 04384 Košice, \\ Slovakia, szaboova.dominika@gmail.com
}

Keywords: services, logistics services, Spiš region

Abstract: This article refers to the application of logistics principles for the purposes of interest increase in the Spiš region. The object of the research is the Spiš region, its structure and range of services. On the basis of system analysis results the recommendations were listed. Practical application of recommendations may increase the interest in the Spiš region and contribute to its development. Certain paragraph contains the time schedule and recommendation implementation costs. After practical application of selected recommendations their effectiveness was. Conclusions are contained in individual paragraph.

\section{Introduction}

Logistics is a cross-cutting science which can be applied in various fields. Traditional logistics concept consisting of the management and implementation of material flows has been expanded by consideration that logistics also includes the transportation of intangible goods, i.e. services. Services as non-material character activities satisfy the needs of consumers. In order to satisfy the demand, it is necessary to ensure adequate services in the issued area; otherwise the decrease in interest can be caused. The object of research is the Spiš region. Through the range of services analysis in the region the deficiencies that reduce its attractiveness can be defined. Through the logistics services principle analysis, systemic activity can be created and can lead to interest increase in this region.

\section{Method of analysis and synthesis}

After examining the various research methods the systems analysis and synthesis were applied. System analysis should provide information necessary for the design of new solutions and synthesis. The result of synthesis should be new, more effective functioning logistics system based on an analysis of the original system or defined on the basis of the acquired theoretical knowledge [1]. The object of research was the Spiš region defined as a system of five components which are interconnected through ongoing flow of information, finance and goods (Figure 1).

Spiš region was divided into five subsystems. Local self-government consists of municipalities and higher territorial units. On the basis of regionalization of the Ministry of Economy of the Slovak Republic in 2005, the territory of the Spiš region consist of 4 districts with a total of 91 local self-governments - municipalities, 6 of them having the statute of the city [2]. Utility lines are on formed by gas distribution lines, electricity and sewerage system. Transport esnsures the connection between self- governments and also ensures the transfer of people and goods. The population is perceived as set of potential customers. Their interest leads to the expansion of offerings services. Services are a set of services that are provided in a given area and affect the quality of life of a resident population.

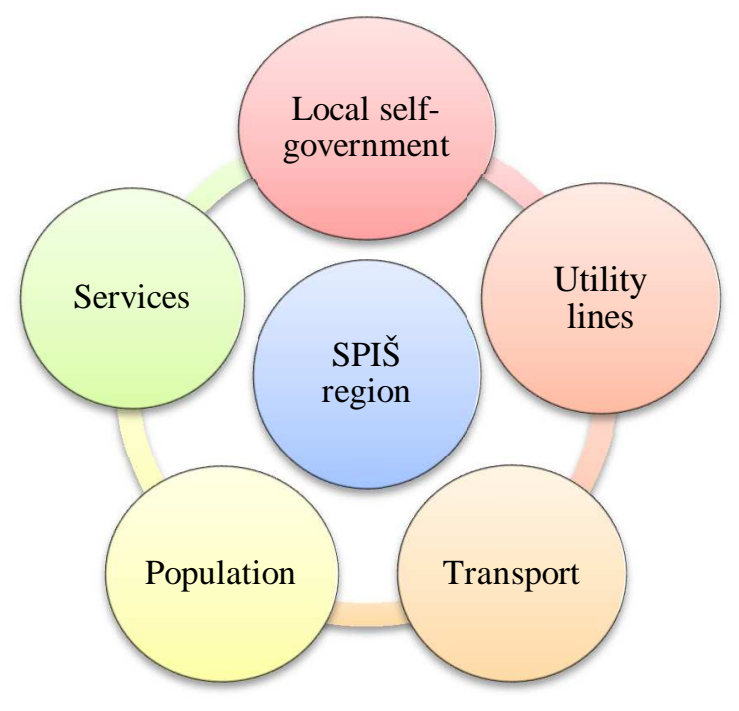

Figure 1 System of the region Spiš

\subsection{System analysis}

Through the system analysis the region was divided into individual local self-governments that were analysed independently in terms of community facilities and range of services which affect the residents' quality of life and represent the potential for future development. Part of the analysis was also a survey, which was performed with a sample of 472 respondents within the period of 8 months. 


\subsubsection{The analysis of territorial units}

The analysis of the Spiš region in terms of community facilities proved inadequate coverage of utility lines. According to the available results, gas distribution lines cover $75 \%$ of the territory, public water distribution system $81 \%$ and sewerage system only $43 \%$ of the region's territory. Railway lines lead just across the quarter of local self-governments and citizens must rely on the bus transportation because roads cover $100 \%$ of the territory. Medical care is provided only in district towns and some larger local self-government.

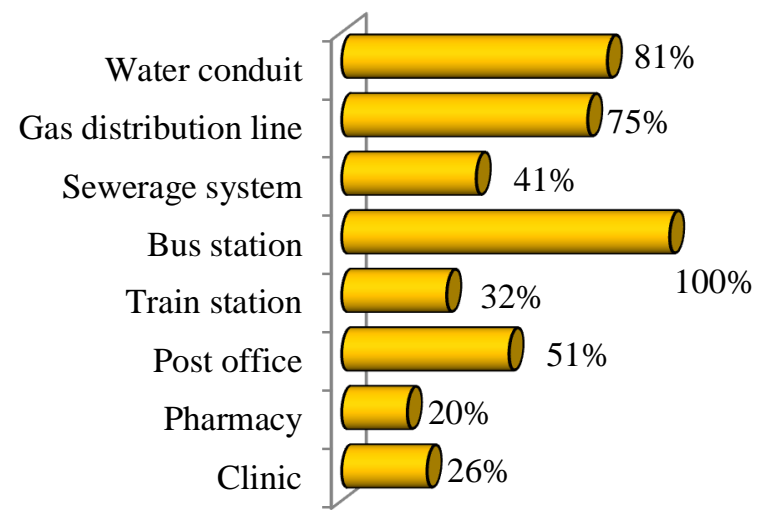

Figure 2 Utility lines in region Spiš

\subsubsection{The analysis of range of services}

In general, the range of services in the region Spiš is various. The offer of basic services (food shops, restaurants, gas stations) is complemented by special services (wellness, aqua park, museum), which can contribute to the development of villages, towns and region as a whole. Although in the cadastre of some selflocal governments historical and technical monuments are located, there is no connection line between them and different segments of services.

\subsubsection{The survey}

The survey revealed that the biggest problem of the region is the lack of information that greatly affects the demand for services. Respondents' answers indicate a high rate of unawareness about region's attractiveness for the domestic population. Respondents have expressed a high level of dissatisfaction with the quality and availability of existing information system and tourist signs. According to foreign respondents the biggest problem is in the region language barrier and lack of information in a foreign language.

\subsection{System synthesis}

In general, the synthesis is the process of creating the new system. Technical aspects of designing are based on projects. Project can be understood as the allocation of resources aimed to achieve specific objectives with planned and organized approach [3]. Project is composed of objectives, tasks, activities and deadlines. Setting a timetable for implementation of the proposed logistics system is the great importance attached to the planning. According to Kootnz and Weihrich (1996) the plan is sequence of activities suitably grouped to achieve the objective [4]. Correct built plan coordinates the efforts of all involved in the implementation of plan and also determines the direction, in which activities should evolve to reach the target [5].

\section{Situation improvement suggestions}

To eliminate deficiencies revealed by the analysis, principles of logistics and methods of planning were applied as well as decision-making and projecting with purpose of creating new logistics system. Lack of information can be solved by application of knowledge from the field of information logistics which is focuses to the management of the information flow.

\subsection{The creation of web}

Generally, the information flow is directly related for demand. According to Gúčik is: "The need for information increases together with the increasing distance from the target destination" [6]. This means that the amount of information which consumer requires about the object of his interest is directly proportional to the distance that separates the consumer and the object of his interest. The most widely used medium for information transfer is the information channel in the form of a website.

\subsection{Geocaching in Spiš region}

Another suggestion is to use the geocaching game as a tool of marketing to promote interesting (lesser known) locations in the region. Geocaching is a playful way to discover interesting locations by using GPS coordinates, suitable for all ages. The principle of the game consists of hiding cache in an interesting location and registration its position, indicating the GPS coordinates on official domain www.geocaching.com that serves as an information channel [7]. Players receive not only information but also an added value of experience associated with finding hidden cache.

\subsection{Visiting of the interesting places Spiš}

Least but no last suggestion to use the potential of region for its future development is creation of sightseeing tours that will connect interesting locations in the region with services with a focus on small businesses. There is no such a product on the domestic market and it represents the potential of the development for the region. Through the cooperation among partners material and information flow will be created, which is necessary for selling goods and further economic development.

This product will enable participating businesses to achieve higher profits by creating new demand in the 


\section{APPLICATION OF LOGISTICS PRINCIPLES FOR THE PURPOSES OF INTEREST INCREASE IN THE SPIŠ REGION \\ Dominika Szabóová}

non-competitive market much easier than rivalry with the competition in existing markets. This strategy is so called theBlue Ocean Strategy, which is based on the creation and use of space for new market demand. The strategy is primarily based on creativity and innovative approach in searching for new markets and opportunities and focuses on the ability to create a sovereign market space [8].

\subsection{Further possibilities of region uniqueness usage}

The region has a wide range of services. There is a lot of uniqueness, which may be interesting to the public. There are many alternatives to create an unique product which can satisfy demand of selected target groups of consumers. The main idea is to achieve the cooperation between organizations, businessmen and craftsmen, who could help to the development of the local economy and the market.

\section{Price calculation of suggestions}

To evaluate the feasibility of the suggestions costs were estimated and incurred in the implementation.

The average cost to set up a web site is between $30-$ 40€. Some hosting companies, like Websupport, enable authors of different projects and interesting ideas to save part of the costs and then a possibility to avoid paying, i.e. $14-15 €$ per year. Thanks to this the installation costs will be reduced by $59 \%$.

Start-up costs for a cache in geocaching game can be $2-5 €$, depending on the complexity of design. Cache consists of a waterproof container containing a pencil and notebook.

The cost of implementation of the last suggestion, sightseeing tours leading through region by bus, will be different depending on the capacity, equipment of the bus, tour and additional services.

It can be assessed that all of the suggestions are feasible and do not require specialized equipment. For successful implementation cooperation between participants based on the outsourcing, under the direction and control of manager or organization, is required.

\section{Suggestion implementation timetable}

According to the general rules of projecting, suggestions require a timetable, which serves as a formal description of the time procedure of activities within the project and provides everyone involved with a comprehensive review of the project [9].

From the timetable it is obvious that the project has been divided into 7 implementation phases. The aim of the project is to increase interest in the region by using of logistics principles. Through the application of various tools of information logistics, methods of logistics planning and projecting of logistics systems, the following table presents few suggestions. Two of them was put into practice during the year 2015 .
Table 1 The timetable for implementation of the project

\begin{tabular}{|c|c|}
\hline Phase of the project & $\begin{array}{c}\text { Orientation time of } \\
\text { implementation }\end{array}$ \\
\hline
\end{tabular}

Phase 1 - Preparation of materials

\begin{tabular}{|l|l}
\hline Analysis and survey & April 2014 - January 2015 \\
\hline
\end{tabular}

Phase 2 - The first promotional activities

Web page creation, search for partners

January 2015 - April 2015

Phase 3 -Stimulate the interest

\begin{tabular}{l|l}
$\begin{array}{l}\text { Promotion between } \\
\text { population, businessmen }\end{array}$ & March 2015 - April 2015 \\
\hline
\end{tabular}

Phase 4 - Maintaining interest and expanding circles of partners

Maintaining interest, partners search

May 2015 - December 2015

Phase 5 - Evaluation of the success of project activities

\begin{tabular}{l|l}
\hline $\begin{array}{l}\text { Reporting the success of } \\
\text { the project activities }\end{array}$ & December 2015 \\
\hline
\end{tabular}

Phase 6 -The implementation

\begin{tabular}{|l|l|}
\hline $\begin{array}{l}\text { Establish a civil } \\
\text { association }\end{array}$ & 2016 \\
\hline $\begin{array}{l}\text { Establish a network of } \\
\text { partner organizations }\end{array}$ & 2018 \\
\hline $\begin{array}{l}\text { Offer cooperation for } \\
\text { schools, travel agencies }\end{array}$ & 2020 \\
\hline $\begin{array}{l}\text { Plan and carry a field } \\
\text { trip /sighseeing tour }\end{array}$ & 2022 \\
\hline Phase 7 - Completion of the project \\
\hline $\begin{array}{l}\text { Completition and } \\
\text { evaluation of project }\end{array}$ & 2024 \\
\hline
\end{tabular}

The first five phases of the project were achieved in the planned time. During the duration of the project efforts were constantly exerted to maintain the interest by developing promotional activities. At the end of the year 2015 the evaluation of the success of project activities was performed. It will serve as a check on the progress.

The most important phase of the project, the implementation phase, has started in 2016. The priority of this year is to establisha civic association and create a network of partners. Aim of the project is the plan for sightseeing tour whichshould be fulfilled by 2022 . The project will be evaluated and completed in the 2024 . 


\section{Success evaluation of implemented suggestions}

During the year 2015 two of the suggestions were realized: the creation of a web and the establishment of caches within the geocaching game.

\subsection{The web and Facebook}

For the establishment of domain, www.kamnaspiši.sk, the company Websupport was chosen, which provided the sponsorship to this project together with Freeweb. Thanks to this operating of domain costs is only $14.76 €$ per year. The website has been accessible to the general public in the Slovak language since April 2015. This website provides the consumer with information about an overview of the facilities, services of the region, events and its attractiveness. The main menu of the domain consists of 7 categories: parts of region, beauties of region, services in region, attractions, events and tip for the weekend.

Google Analytics was installed for better monitoring of operation of this site and number of visitors. This tool allows you to make various reports about visit rate, readership of articles and effectiveness of current advertising campaign [10].

From the records it is obvious, that the website after its publication in April 2015, has gained interest of public. In next few months was attended by 780 to 1,000 of internet users per month. Popularity significantly decreased in September 2015 to a level of 500 visits per month and this trend was maintained for the remainder of 2015. In January 2016 it can be observed a slight increase in interest of public over 600 visitors per month.

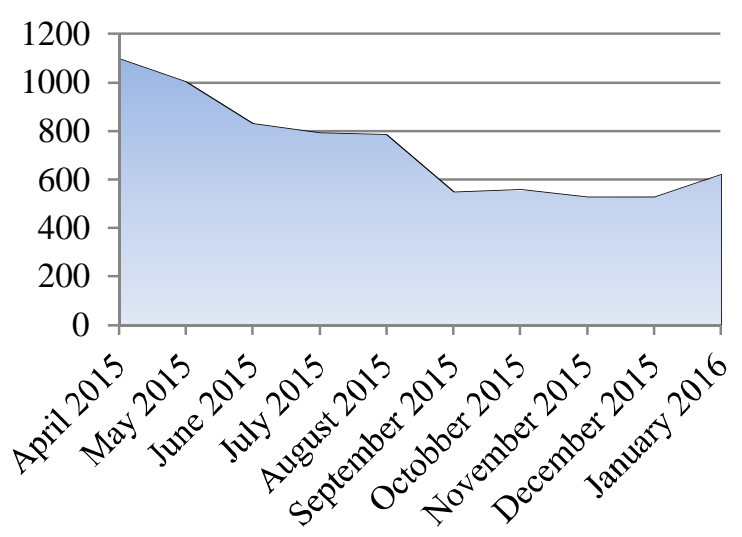

Figure 3 The number of visitors on domain www.kamnaspiši.sk

The analysis of visit rate demonstrates that returning visitors represent $17.40 \%$ of all visitors and the remaining $82.60 \%$ are new visitors.

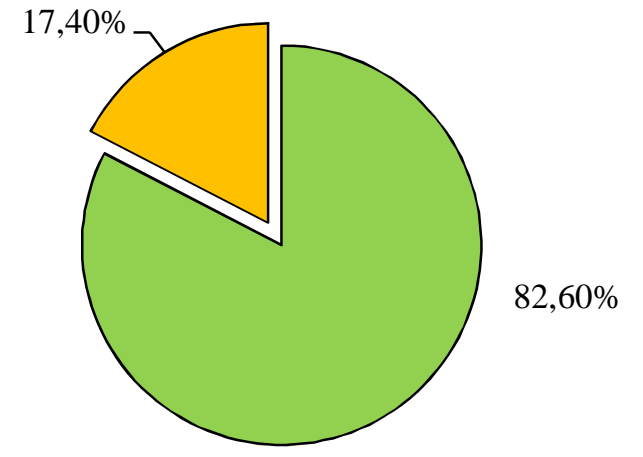

$\square$ New visitors $\square$ Returning visitors

Figure 4 New visitors vs. returning visitors

According to records from Google Analytics $83 \%$ of all website visitors are residents of the region Košice and Prešov. According to available data, $60 \%$ of all visitors are residents of the district Spišská Nová Ves, visitors from Bratislava and the surrounding present $14 \%$, from Košice and surrounding present $13 \%$, inhabitants of Prešov and surrounding present $6 \%$ of and Poprad inhabitants represent $3 \%$ of total visits. Inhabitans form other county towns represent almost $1 \%$ of all visitors. These figures point to the fact that website www.kamnaspiši.sk is known only in Spiš region, mostly in the district Spišská Nová Ves, but brand awareness is slowly spreading to other areas of Slovakia.

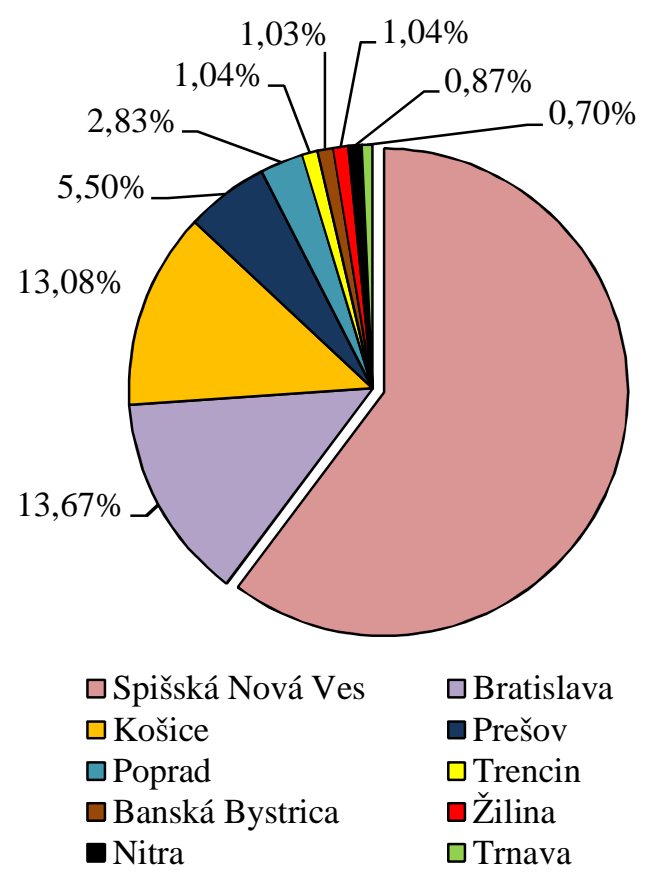

$60,24 \%$

Figure 5 The visit rate according to permanent resident of visitors 


\section{APPLICATION OF LOGISTICS PRINCIPLES FOR THE PURPOSES OF INTEREST INCREASE IN THE SPIŠ REGION \\ Dominika Szabóová}

In order to raise awareness of this website www.kamnaspisi.sk were placed posters in region and created Facebook profile. During his nine-month existence gained more than 460 fans. Facebook is used as an information channel. Through social network can different users shared links to the various events and attractions of the region.

In October 2015 were extend marketing and promotion activities. Was closed cooperation with the administrator of local information portal www.snv.sk.Cooperation involves updating the calendar of events organized in the town Spišská Nová Ves on the domain www.snv.sk.In exchange, banner which presents the project kamnaspiši was placed on the domain www.snv.sk.

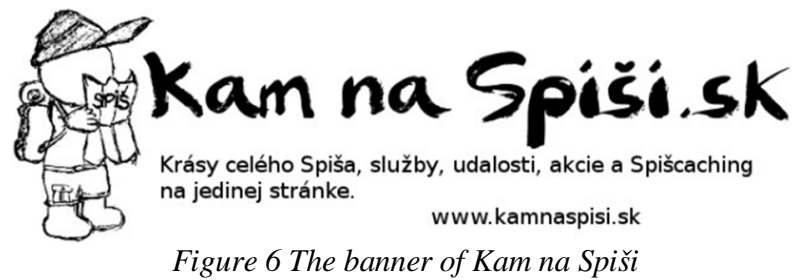

Thanks to Google Analytics is possible to calculate, that $63 \%$ of all visitors discovered domain www.kamnaspiši.sk through social network Facebook. The domain www.snv.sk attracted $14 \%$ of visitors to kamnaspiši domain. The remaining $23 \%$ of visitors seek kamnaspiši domain directly or through other intermediate links. These results also demonstrate, that is important to continually expand marketing and promotional activities. Thanks to then will the website kamnaspiši get into ears to the inhabitants of other areas of Slovakia and later beyond national borders. For this step is necessary to create the language modification of website and Facebook.

\subsection{Geocaching in Spiš}

Under the pilot project called Spiš Caching were in the region Spiš hidden 13 caches. Since its inception in May 2015 until January 2016 (including), these caches discovered 779 users and most of them said, that they haven't known about the existence of such beauties and treasures. For example it can be geyser Sibá brada, metallurgical factory in Štefanská Huta or Lake Úhorná. These findings suggest that game geocaching can be used as a marketing tool.

\subsection{Project partners}

The basis for the successful completion of the project kamnaspiši is cooperation of organizations, businessmen and craftsmen. Over the past months there were a number of negotiations with businessmen and interest associations. The results are several agreements on mutual promotion. To this day are involved businessmen (Levos Nálepkovo, Grower distillery
Smižany), local self-governments (Smolník, Rudnany, Pavl'any, Dlhé Stráže, Levoča, Spišská Nová Ves), interest associations (KSTAC Lokomtíva Bane - SNV, TK Vojkovce Slubica), civil associations ( Sans Souci summerhouse Iliašovce, mining museum Hnilčík, Shelter for dogs - Happy dog Matejovce nad Hronádom) and state institutions (Spiš Museum in Levoča).

Cooperation with these subjects will be developed, as well as effort will be made to find additional partners to establish a comprehensive product of services and experiences. The product of this character is missing in the domestic market and is a potential for development of the region. For successful implementation is necessary to create a network of suppliers in the place of the stops of future sightseeing tour. Suppliers will ensure that the desired product or service will be provided at the required location, in the required time and in the required quality and quantity.

\section{Conclusion}

The main problem of the region is insufficient application of the principles of logistics. The result is a decrease of interest in the region, which significantly affects the level of employment and quality of resident's life. The analysis showed that the biggest problem of the region Spiš is an inadequate information flow and missing connections between sights and monuments. On another hand, the region has a wide range of services and has a lot of uniqueness, which can be the subject of interest. In order to use the potential of the region for its future development were in this article presented various suggestions, which are characterized by the need for mutual connection of the individual components examined logistics system.

The aim of local self- governments is satisfy the needs of resident population. Tool for it is range of services, which should be continually expanded according to public interest. In order to maintain sales or elicit demand for services and products is important not to neglect the power of information and marketing. Information flow considerably affects the purchasing behaviour of consumers.

Ambition of presented suggestions is to create a network of partner's businessmen and various organizations, which would bring to the market a new unique product. This common product, themed trips or sightseeing tour, can increase interest of region Spiš. Participant will obtain all the services, which he needs for satisfaction of needs. During the trip or tour he will obtain information and also the added value of the experience.

Discovering interesting places in region or city using organized trip is the most frequently was to increase the purchasing behaviour of consumers abroad. The offer is interesting for consumers because his needs to visit the place will be filled; he has a comfortable transfer to the destination and back and often arise savings. 
Demand for this product would provide material and financial flows that are essential for the development of the region. Formation of new market opportunities not only affect the development of the region and can ultimately lead to the creation of new job positions.

\section{References}

[1] MALINDŽÁK, D., TAKALA, J.:Designing logistics systems (theory and practice), Košice, Expres publicit s.r.o., 221 p., 2005. (Original in Slovak).

[2] 'Regionalization of tourism in Slovakia', The Ministry of Economy of the Slovak Republic, Department of Tourism, 93 p., 2005. (Original in Slovak).

[3] LIENTZ, B. P., REA, K. P.:Project Management for the 21st century, 2nd edn., San Diego, CA: Academic Press, 1998. (Original in English).

[4] KOONTZ ,M., WEIHRICH,H.:Management, Praha, Victoria Publishing, 659 p., 1993. (Original in Czech).

[5] SOJKA, L.:Basics of management, 1st edn., Prešov, Faculty of management, 104 p., 2007. (Original in Slovak).

[6] GUČÍK, M.:Tourism: Introduction to the study, Banská Bystrica, Dali-BB, 307 p., 2010. (Original in Slovak).

[7] KUBLINIAK, M.:Geocaching in Sovakia, [Online], 2006, Available:http://www.geocaching.sk/co-je-togeocaching.php, [04 Feb 2016]. (Original in Slovak).

[8] 'Blue Ocean Strategy', Management mania, [Online] 26 April 2013, Available: http://managementmania. com/cs/blue-ocean-strategy, [04 Feb 2016]. (Original in Czech).

[9] KRŠÁK, B. et. al.:Project Management: Textbook Instructions for exercises, Košice, Rozmar, 135 p., 2008. (Original in Slovak).

[10] REITER, M.:Review: Google Analytics - Web under supervision, Itnews [Electronic] 26 April 2013, Available: http://www.itnews.sk/tituly/pc-revue/201304-26/c155914-recenzia-google-analytics-web-poddohladom?page $=0, \quad[04$ Feb 2016]. (Original in Slovak).

\section{Review process}

Single-blind peer reviewed process by two reviewers. 